\title{
Game management and cultural survival: the Yuquí Ethnodevelopment Project in lowland Bolivia
}

\author{
A. M. Stearman and K. H. Redford
}

When the Yuqui Indians of Bolivia adopted a settled life-style in the 1960s, wild animals continued to be their main source of meat. As a result, game species declined in numbers around their settlement and their problems were exacerbated by colonists seeking new lands to farm. Prospects brightened in 1992 when 115,000 ha of land were designated Yuquí Indigenous Territory. This paper describes how a system of satellite camps was developed to enable the Yuqui to exploit game animals sustainably and to defend their land from encroachment.

\section{Introduction}

In many parts of the world hunting remains an important subsistence activity. In at least 62 countries, wildlife and fish contribute a minimum of 20 per cent of the animal protein in the diets of the human inhabitants (PrescottAllen and Prescott-Allen, 1982). In the forested regions of Latin America, game provides an important contribution to the diets of most rural populations and to indigenous peoples in particular. The indigenous peoples of Amazonia, many of whom depend solely on game for animal protein, are being adversely affected as settlers encroach on their traditional hunting territories. Habitat destruction and competition for bush meat are making game animals scarce.

The Yuquí Indians of eastern Bolivia are but one of many indigenous groups facing new challenges as exposure to modern society changes old patterns of subsistence and the presence of settlers threatens a once dependable resource base. Unlike most native Amazonians, however, the Yuquí have been offered some unusual opportunities to protect their hunting grounds from settler invasion and practise management strategies for more sustainable wildlife harvests.

\section{Effects of settler encroachment on the Yuquí}

Prior to contact by missionaries in the mid1960s, the Yuquí Indians of the Bolivian Amazon were one of the few remaining nomadic hunting-and-gathering peoples in the world. They were true foragers, depending only on the resources of the forest they inhabited for their livelihood. Without the security of crops, they moved almost constantly in pursuit of game, honey, fruit and other foods necessary for subsistence. At the time of contact, the first of three bands, all of which were eventually settled at the mission station on the Chimoré River (16 $\left.46^{\circ} \mathrm{S} 64^{\circ} 56^{\circ} \mathrm{W}\right)$, numbered only 43 people (Stearman, 1989). With natural increase and the addition of two more groups contacted, the Yuquí population has reached almost 150.

The Yuquí are now sedentary and practise some agriculture, but continue to depend on foraging for much of their dietary intake. A few domestic animals, such as chickens, are kept sporadically but the only consistent source of animal protein consumed is provided by what is captured in the forest or taken from the rivers. Unfortunately, they find themselves in a region of Bolivia that is being settled by colonists from the highlands who are seeking new lands to farm. 


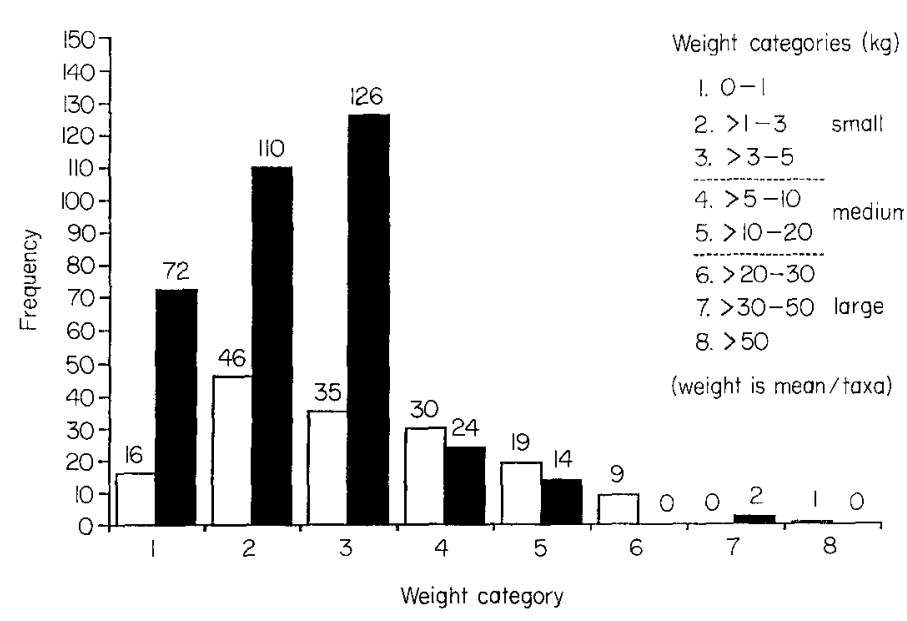

Figure 1. Comparisons of frequency of game takes by weight category between 1983 ( $\square$ ) and 1988 ( $\square$ ).
Sedentarism and population growth among the Yuquí have contributed to local depletions of fauna, as might be expected from people hunting continually around a permanent settlement. Of greater consequence to Yuquí well-being, however, is the depletion over a wider area of the larger game animals, such as white-lipped peccary Tayassu pecari, capybara Hydrochaeris hydrochaeris and tapir Tapirus terrestris, all intensively hunted by colonists and all threatened by habitat loss and fragmentation. Studies conducted by A.S. over 56-day periods in 1983 and 1988 revealed a remarkable decline in game meat procured over these 5 years. In 1983, the Yuquí were consuming 88 grams of protein per capita per day, amounts that were more than adequate to meet average daily requirements. By 1988, however, protein consumption had dropped to less than half that amount, or 40 grams per capita per day, far below the recommended daily intake (Stearman, 1990)

The data for 1983 show 156 game animals taken, representing 27 taxa with a total live weight of $1169 \mathrm{~kg}$. Of these, 62 per cent were small game $(0-5 \mathrm{~kg})$. By 1988 , in order to maintain previous game-take levels, the number of animals taken had grown to 348 individuals representing 44 taxa. The proportion of small animals taken had also increased to 88 per cent of the total (Figure 1). In 1983, only five species - deer Mazama americana, tapir, capybara, collared peccary Tayassu tajacu and white-lipped peccary - accounted for 65 per cent, by weight, of the total game taken (Stearman, 1990). The data are consistent with the proposition that the continuing availability of these large animals allowed hunters to take fewer species of game animals, fewer numbers and fewer of the less-preferred species (such as coatis Nasua nasua, which are considered to have inferior-tasting meat). The presence of the larger game animals, particularly whitelipped peccaries, which run in herds that can exceed 200 animals, provides small indigenous groups such as the Yuquí with consistent and substantial sources of animal protein in an otherwise patchy environment ( $c f$. Vickers, 1990). In 1988 tapir, white-lipped peccaries and capybara did not appear in the Yuquí hunting sample.

An extension of studying patterns of game use among the Yuqui was an interest in the question of how much land the Yuqui would require to be able to continue their traditional foraging patterns for at least another generation. Using the hunting data sets from 1983 and 1988 provided by Stearman, Redford and Robinson estimated that in order to continue hunting on a sustainable basis, the Yuquí would need territory of at least 100,000 ha (Stearman, 1990). However, the process of acquiring legal rights to any amount of land for the Yuquí had until this point been a daunting and largely unsuccessful bureaucratic undertaking. Then, in 1992, a fortuitous series of 


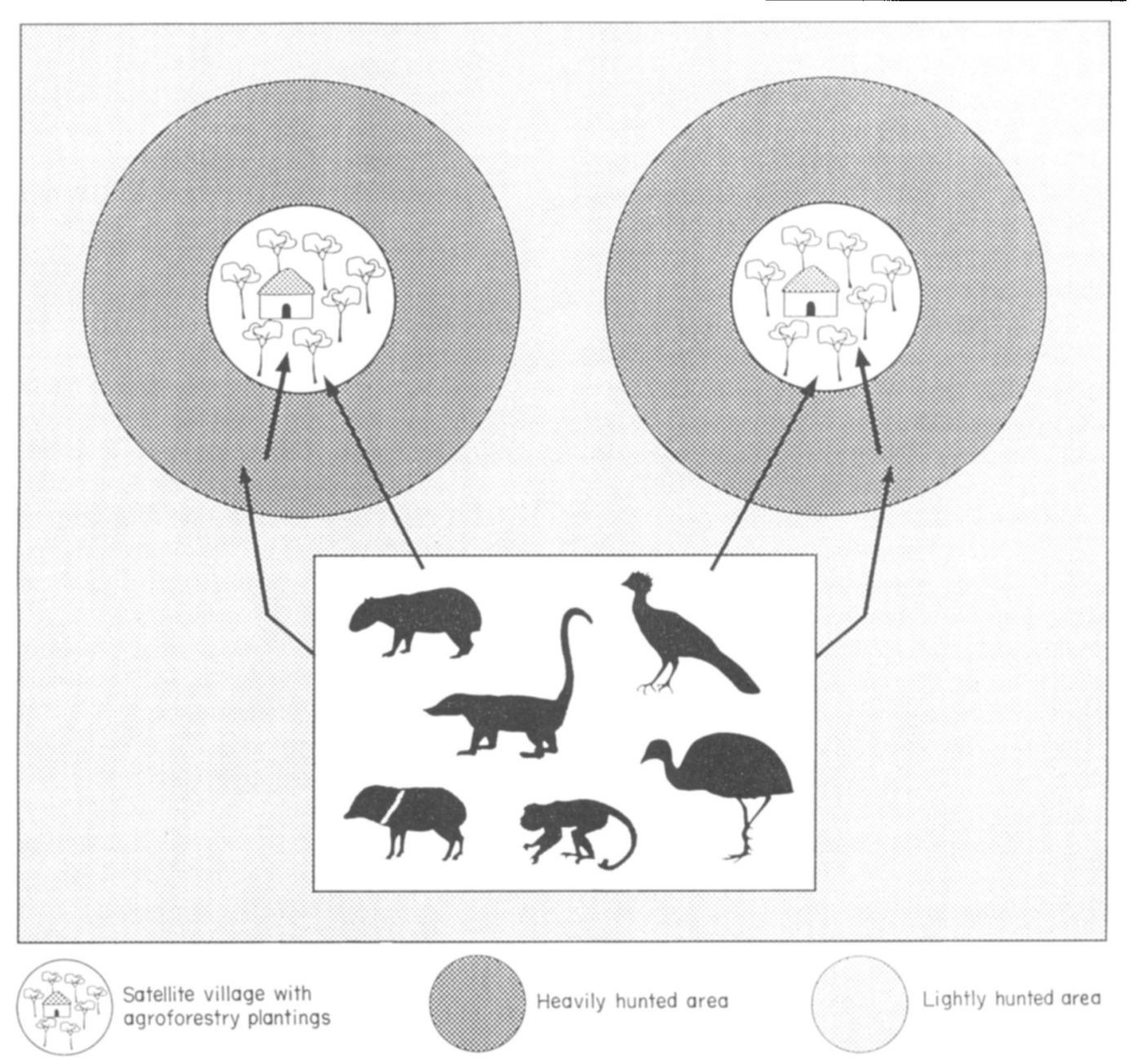

Figure 2. Schematic representation of satellite agroforestry camps with relative intensity of hunting pressure.

events suddenly brightened prospects for obtaining a Yuquí homeland.

\section{The Yuqui Ethnodevelopment Project}

In early 1992 the Yuquí were targeted to receive funding assistance from an Interamerican Development Bank (IDB) loan to Bolivia to offset the negative effects of the construction of a major highway linking the cities of Santa Cruz and Cochabamba. With 10 years' experience working among the Yuquí, the IDB invited A.S. to $\mathrm{La} \mathrm{Paz}$ to discuss planning and directing a Yuquí ethnodevelopment project. During this visit, A.S. learned that the President of Bolivia shortly would be hosting an international conference to announce the founding of the Indigenous Fund for Latin America and, to underscore his support of land rights for indigenous peoples, he would recognize by Presidential Decree four indigenous territories at the opening ceremonies. Stearman was told that the Yuquí were being considered as possible recipients, and was asked if she could assist in the preparation of the necessary documents. She immediately travelled to the lowlands to discuss the prop- 
osition with the Yuquí, who responded enthusiastically. Of significant importance in this process was having the research data at hand to support not only the urgent need to set aside this land for the Yuquí, but also to increase the original government offer of less than 50,000 ha to over 100,000 ha. On 9 April 1992, the President of Bolivia signed a Presidential Decree establishing 115,000 ha of land as the Yuquí Indigenous Territory.

Less than 2 months after the signing of the decree, A.S. returned to Bolivia to direct the Yuquí Ethnodevelopment Project. Among the initial concerns of the project team were demarcating the new territory, halting the advance of colonists into Yuquí lands and dealing with the growing problem of game scarcity. While the majority of the territorial boundaries were rivers and could be mapped quickly and relatively easily by boat using a Global Positioning System (GPS) unit, the southern boundary was a line that had to be cut through the forest. This line also bordered the area of greatest colonist penetration and would need almost constant vigilance. At the same time it was necessary to devise strategies that would encourage the Yuquí to expand their hunting into areas previously unknown and unhunted by them, thus relieving exploitation pressure on areas nearest to Yuquí habitation and areas of established settlement by colonists.

\section{Game management strategies}

Redford arrived during the first month of the project to assist with developing ways to address these and other more specific issues related to game management. Following several meetings with the community, he tackled the interrelated problems of increasing game scarcity and threats to the integrity of Yuquí land from settler incursion.

The result was a proposal to establish satellite encampments scattered throughout the Yuqui territory. These would be designed to attract game while at the same time providing agreeable camping spots for the hunters and their families (Redford, 1993). The satellite camps were to be based on agroforestry plantings that incorporated wild and domestic fruit trees. These trees would provide fruit directly to the Yuquí and also serve to attract, and perhaps increase, the populations of important game species, many of which rely on fruit for a major portion of their diet (Figure 2). Fortunately, there is a high degree of overlap between the trees producing fruit eaten by humans and those producing fruit eaten by game animals (Redford et al., 1992).

The camps would be sited according to: (1) strategic location; (2) agreeable location; and (3) spacing. The first two criteria are discussed elsewhere in this paper. The criterion of 'spacing' is particularly important in that the system of satellite camps can only be applied in areas of low human population density with large tracts of relatively undisturbed habitat and the camps must be located a minimum distance apart. Around each camp there will be an area (approximately $5-10 \mathrm{~km}$ radius from the camp, or what a hunter can travel and still return to camp at night) that receives heavy hunting pressure. This area will have a lower density of animals than the surrounding forest and, because of lower game densities, will serve as a 'sink' into which animals from the less-hunted areas will move. If placed too closely together, each agroforestry-game system would attract game animals from only a small catchment basin, or several overlapping basins. The result would be over-harvesting and eventual local extinction of the game population. However, if the catchment basins are relatively large, non-overlapping and not heavily disturbed, then a viable breeding population of game could more easily be maintained and the system could be sustainable.

There are some species, such as the tapir and some of the larger primates, that have reproductive rates so low that it would be difficult to sustain hunting pressures (Bodmer et al., in press). These species will probably be very much reduced in density in much of the Yuquí Territory. Other species, such as collared peccaries, agoutis and deer, are much more suitable candidates because of their higher reproductive rates. Ideally, no matter 
what the species, attempts should be made to minimize the killing of adult females, particularly during the reproductive season.

\section{Satellite agroforestry-game camps}

Following K.R.'s recommendations, three Yuquí men were selected and trained to serve as forest guards. They were provided with credentials by the Bolivian Forestry Department and a letter from the Secretariat for the Environment authorizing the halting of further colonization and the right to confiscate products illegally removed from the forest. Plans were then made to establish two initial satellite camps at strategic locations within the Territory. These were established along the southern boundary line at distances exceeding $10 \mathrm{~km}$ from the main settlement. At the outset it was decided to erect a large, open house at each site, made from local materials but with a durable tin roof. The Yuquí and project staff felt that the apparent permanence of these buildings would lend weight to the seriousness of the Yuquí in defending this line against further movement by nearby colonists. The effect on the settlers was sobering: the appearance of these structures was a strong signal of Yuquí determination to defend their lands.

Once the structures were complete, small areas of forest around each camp were cleared and planted with perennial or semi-perennial domestic crops, such as plantains and manioc for human and game animal consumption, and native fruit trees. The camps have proved remarkably successful. The Yuquí forest guards patrol the southern boundary once a month, passing one night in each house. They are frequently accompanied by several Yuquí hunters and their families. The ample trail houses provide comfortable shelter, lend a sense of novelty to the hunt and are considered safe places in an area formerly regarded as being too distant from the home community to be visited safely.

While measurement of the effects of these camps on game densities and hunting success has not yet been undertaken, anecdotal infor- mation confirms that the area is much richer in fauna than any under traditional exploitation and is serving an important function of drawing the Yuquí away from over-hunted areas. The Yuquí are particularly pleased that troops of the larger primates such as howler monkeys Alouatta spp. and spider monkeys Ateles spp. are plentiful, these animals having long since disappeared from the settlement environs. The combination of having permanent shelters with plant foods available and the promise of good hunting has proven irresistible to the Yuquí; more families are eager to participate in walking the boundary, which has the added benefit of increasing their visibility to colonists. There is also indication that enriching the forest with edible plants is attracting game. One group of Yuquí returned from an extended hunt to report that a tapir was foraging around one of the camps and appeared to have actually taken up temporary residence in the house. Yuquí hunters also have been successful in harvesting the highly valued white-lipped peccary and capybara in this area, the meat from which is smoked and carried back to the main settlement. However, there has been resistance to the suggestion that the taking of females be avoided during the reproductive season.

\section{Conclusions}

The system of satellite camps described in this paper is not new, but is based on well-established practices of Amazonian indigenous peoples who have long recognized the relationship between game animals and fruiting trees (Denevan and Treacy, 1987; Irvine, 1987). The primary role of the camps is a strategic one - enabling and encouraging the Yuquí to patrol the boundary of their territory most threatened by settler incursion. The major attraction to perform such patrolling is better hunting. It seems clear that Yuquí hunters are currently experiencing better hunting success, undoubtedly due to hunting in previously unhunted forest. The second major role of the camps is to attempt to ensure that this hunting success is maintained after the initial period of 
exploitation. The expectation is that enriching the forest combined with only occasional bouts of hunting will concentrate, and perhaps even increase, the populations of some game species. It is hoped that management schemes such as this will be tried in numerous areas of the tropics and that lessons learned from the failures and successes will allow the protection of both indigenous land rights and many components of tropical forests.

\section{References}

Bodmer, R.E., Fang, T.G., Moya, I. and Gill, R. (in press). Managing wildlife to conserve Amazonian forests: population biology and economic considerations of game hunting. Biological Conservation.

Denevan, W.D. and Treacy, J.M. 1987. Young managed fallows at Brillo Nuevo. In Swidden-fallow Agroforestry in the Peruvian Amazon (eds W. M. Denevan and C. Padoch), pp. 8-46. Advances in Economic Botany, 5, 1-107.

Irvine, D. 1987. Resource Management by the Runa Indians of the Ecuadorian Amazon. PhD thesis, Stanford University.

Prescott-Allen, R. and Prescott-Allen, C. 1982. What's Wildlife Worth? International Institute for Environment and Development, Washington, DC.

Redford, K.H. 1993. Managing the Forest: Fruit Trees and Game Species on Yuqui Indian Lands. Report to
Dr Allyn MacLean Stearman, Subproyecto Protección de Etnias. Secretaría Nacional del Medio Ambiente/Banco Interamericano de Desarrollo/University of Central Florida.

Redford, K.H., Klein, B. and Murcia, C. 1992. The incorporation of game animals into small-scale agroforestry systems in the Neotropics. In Conservation of Neotropical Forests: Building Traditional Resource Use (eds K. H. Redford and C. Padoch), pp. 333-358. Columbia University Press, New York.

Stearman, A.M. 1989. Yuquí: Forest Nomads in a Changing World. Holt, Rinehart and Winston, New York.

Stearman, A.M. 1990. The effects of settler incursion on fish and game resources of the Yuquí, a native Amazonian society of eastern Bolivia. Human Organization, 49 (4), 373-385.

Vickers, W. 1990. Hunting yields and game composition over ten years in an Amazonian Indian territory. In Subsistence and Commercial Uses of Neotropical Wildlife (eds J. G. Robinson and K. H. Redford), pp. 53-81. University of Chicago Press, Chicago.

Allyn MacLean Stearman, Department of Sociology and Anthropology, University of Central Florida, Orlando, FL 32816, USA.

Kent $H$. Redford, Conservation Science and Stewardship, Latin American Division, The Nature Conservancy, 1815 North Lynn Street, Arlington, VA 22209, USA. 